\title{
Peranan Bakteri Indigenus dalam Degradasi Limbah Cair Pabrik Tahu
}

\section{The Role of Indigenous Bacteria in Degrading Liquid Waste of Tofu Production}

\author{
Retno Ken $\mathbf{R}^{1}$, A. Wibowo Nugroho Jati ${ }^{1 *}$, L. Indah Murwani Yulianti ${ }^{1}$ \\ ${ }^{I}$ Prodi Biologi, Fakultas Teknobiologi, Universitas Atma Jaya Yogyakarta \\ Jl. Babarsari No.44 Yogyakarta 55281 Indonesia \\ email: wibowo.jati@uajy.ac.id *Penulis korespondensi
}

\begin{abstract}
Tofu making mostly go through the traditional process and it produces liquid and solid wastes. The organic substance contained in the liquid waste is many. The liquid waste disposal to the river and lake can pollute the water, reduce the oxygen in the water, and harm the underwater life. It is necessary to do tofu wastewater treatment for example by bioremidiation using bacteria. Therefore, this study was conducted to determine the characteristics of indigenous bacteria in liquid waste of tofu and to use these bacteria for tofu wastewater treatment. The Research result showed the characteristic of isolate $R 3$ is suggested as genus of Pseudomonas sp and isolate R7 is suggested as genus of Bacillus $\mathbf{s p .}$ Treatment A (using R3 microbe) can reduce $1 \%$ of COD, 33\% of BOD, $2.9 \%$ of TSS, $12 \%$ total-N and increase $21 \%$ of TDS and $1.9 \%$ of amylum. Treatment B (using R7 microbe) can reduce $1 \%$ of COD, $59 \%$ of BOD, $5.2 \%$ total-N and increase $21 \%$ of TDS and $46 \%$ of amylum. Treatment $\mathrm{C}$ with adding $\mathrm{R3}$ and $\mathrm{R} 7$ microbes degrades more organic substance in wastewater because it can increase $\mathrm{pH}$ and temperature faster and decrease $\pm 1 \%$ of COD, \pm $23 \%$ of BOD5, $21 \%$ of TDS $8.1 \%$ of TSS, $8.9 \%$ of total-N and $34 \%$ of carbohydrate (amylum).
\end{abstract}

Keywords: Biodegradation, liquid waste of tofu, indigenous bacteria, waste treatment

\begin{abstract}
Abstrak
Produksi tahu banyak dilakukan secara tradisional dan menghasilkan limbah cair serta padat dari proses pembuatannya. Kandungan bahan organik yang dihasilkan oleh limbah cair tahu sangat tinggi. Air limbah yang dibuang secara langsung ke air permukaan (sungai dan danau) dapat mencemari air, mengurangi oksigen dalam air dan akan mengganggu kehidupan organisme di dalamnya. Pengolahan limbah cair tahu perlu dilakukan misalnya dengan bioremidiasi menggunakan bakteri. Oleh karena itu, penelitian ini dilakukan untuk mengetahui karakteristik bakteri indigenus dalam limbah cair tahu dan menggunakan bakteri tersebut untuk pengolahan limbah cair tahu. Karakteristik isolat R3 diperkirakan Pseudomonas sp., sedangkan bakteri R7 diperkirakan Bacillus sp. Perlakuan A (menggunakan isolat R3) mampu menurunkan COD 1\%, BOD 33\%, TSS 2,9\% dan N-Total $12 \%$ serta meningkatkan TDS $21 \%$ dan amilum 1,9\%. Perlakuan B (menggunakan isolat R7) mampu menurunkan COD 1\%, BOD5 9\%, amilum 46\%, N-Total 5,2\% serta meningkatkan TDS 21\%. Perlakuan $\mathrm{C}$ dengan penambahan bakteri R3 dan $\mathrm{R} 7$ lebih banyak mendegradasi limbah organik yang ada di dalam limbah karena mampu menaikkan pH dan suhu paling cepat dan menurunkan COD sebesar $\pm 1 \%$, kadar BOD5 sebesar $\pm 23 \%$, kadar TDS sebesar $21 \%$, TSS sebesar 8,1 \%, N-Total sebesar 8,9\% dan kadar karbohirat (amilum) sebesar $34 \%$.
\end{abstract}

Kata Kunci : Biodegradasi, limbah cair tahu, bakteri indigenus, pengolahan limbah

Diterima: 2 Desember 2018, disetujui: 4 Januari 2019

\section{Pendahuluan}

Indonesia memiliki industri tahu yang besar. Produksi tahu banyak dilakukan secara tradisional dan menghasilkan limbah cair serta padat dari pembentukan tahu. Bahan organik yang dihasilkan oleh limbah cair tahu sangat tinggi. Secara fisika dan kimia limbah cair tahu 
dapat diidentifikasi dari padatan total yang dihasilkan, suhu yang didapatkan, warna serta aroma (bau) ditimbulkan, bahan organik dalam limbah, bahan anorganik serta gas yang ditimbulkan. Kebanyakan limbah cair dari industri tahu ini langsung dibuang tanpa pengolahan terlebih dahulu. Limbah yang dibuang di badan sungai mencemari lingkungan, berwarna keruh susu, berbau busuk dan menghasilkan busa (Wigyanto dkk., 2009).

Pelaksana industri dituntut memiliki sistem pengolahan limbah yang baik dan telah diatur dalam Peraturan Menteri Lingkungan Hidup Indonesia agar saat dibuang ke lingkungan (air, udara ataupun tanah) tidak menyebabkan pencemaran (sesuai baku mutu lingkungan). Namun, untuk industri skala kecil (rumah tangga) hal tersebut masih belum terlaksana dengan baik karena belum memiliki sistem pengolahan limbah yang memadai, dan kebanyakan limbah dari industri kecil (industri rumah tangga) langsung dibuang ke lingkungan tanpa melalui proses pengolahan (Rizki dkk., 2007).

Air limbah yang dibuang ke air permukaan (sungai dan danau) mencemari air permukaan, air limbah akan mengurangi oksigen dalam air sehingga mengganggu kehidupan di dalamnya. Selain itu, air limbah juga bisa mencemari air dalam tanah sehingga fungsi air tanah menjadi berkurang (Wijaya, 2008). Jika air limbah merembes ke tanah dekat sumur maka kualitas air sumur tidak bagus lagi, yang dapat menimbulkan gangguan kesehatan seperti gatal, diare, kolera, radang usus dan lainnya terkait air kotor (Pohan, 2008).

Bioremediasi memanfaatkan makhluk hidup yang merombak substansi atau bahan berbahaya bagi lingkungan menjadi komponen tidak berbahaya bagi lingkungan. Salah satu alternatif yang digunakan untuk mencegah kerusakan lingkungan dari limbah cair tahu tersebut adalah dengan menggunakan bakteri yang berpotensi untuk merombak polutan. Limbah tersebut diurai bakteri sampai volumnya lebih sedikit melalui reaksi enzimatis. Bakteri mampu menurunkan bahan organik di dalam limbah cair tahu dengan kenaikan $\mathrm{pH}$, serta penurunan nilai BOD dan COD (Wigyanto dkk., 2009).
Perlunya pengkajian mengenai bakteri indigenus dalam limbah tahu dan perannya dalam bioremidiasi mendorong pelaksanaan penelitian ini dengan tujuan untuk karakterisasi bakteri indigeneus yang mendominasi limbah cair tahu dan mengetahui isolat bakteri yang paling efektif dalam mendegradasi limbah cair tahu.

\section{Metode Penelitian}

\section{Alat dan Bahan}

Alat utama yang digunakan dalam penelitian terdiri dari timbangan analitik, toples, selang, gelas ukur, pH, TDS meter, termometer, aerator, shaking incubator, serangkaian alat destilasi, autoklaf, LAF, inkubator. Bahan utama berupa limbah cair tahu, medium Nutrient Agar, dan Medium Nutrient Broth.

\section{Rancangan Percobaan}

Penelitian dengan Rancangan Acak Lengkap (RAL) menggunakan empat perlakuan dan setiap perlakuan dilakukan tiga kali pengulangan dan dilakukan pengamatan parameter untuk setiap pengulangan dan perlakuannya. Perlakuan terdiri dari kontrol negatif (tanpa penambahan bakteri), perlakuan A (penambahan bakteri R3), perlakuan B (penambahan bakteri R7), perlakuan C (penambahan bakteri R3 + R7). Dilanjutkan analisis data menggunakan ANOVA dan Duncan Multiple Range Test (DMRT).

\section{Tahapan Penelitian}

Sampel limbah cair tahu diambil kemudian dilakukan pengenceran $10^{-1}$ sampai $10^{-5}$. Masing-masing seri pengenceran diambil dan diisolasikan pada medium NA. Karakterisasi isolat bakteri diawali dengan tahap pengamatan morfologi bakteri (seperti bentuk, elevasi, margin, warna dan permukaan koloni), pengecatan gram, uji katalase, uji sifat biokimia yaitu uji fermentasi karbohidrat (glukosa, sukrosa dan laktosa), uji reduksi nitrat, uji pembentukan indol. Hasil uji karakterisasi dibandingkan dengan buku Bergey's Manual of Determinative Bacteriology 7th edition untuk dilakukan identifikasi jenis isolat yang ditemukan. 
Isolat diperbanyak dan dilakukan tahap aplikasi sederhana pada limbah dengan membandingkan hasil uji dari parameter $\mathrm{pH}$, suhu, COD, BOD5, TDS, TSS, kadar amilum (karbohidrat) dan N-total selama aplikasi. Lalu dilakukan analisis data menggunakan SPSS. Parameter $\mathrm{pH}$, suhu dan TDS diukur setiap hari selama 7 hari pelaksanaan menggunakan alat $\mathrm{pH}$ meter dan TDS meter, sedangkan konsentrasi amilum (karbohidrat) yang diuji menggunakan metode Luff Schoorl, BOD5, COD, TSS, dan konsentrasi N-Total diukur pada hari ke-0 dan hari ke-7.

\section{Hasil dan Pembahasan}

\section{Isolasi bakteri dominan}

Isolasi bakteri indigenus dominan diambil dari pengenceran pada sampel limbah cair tahu mulai dari pengenceran $10^{-1}$ sampai pengenceran $10^{-5}$ yang kemudian diisolasi pada medium agar dan diinkubasi 24 jam pada suhu $37^{\circ} \mathrm{C}$. Penentuan koloni bakteri dominan dilakukan dengan cara menghitung jumlah koloni dan dilihat morfologi koloni dari bentuk, tepian, elevasi, warna, dan jumlah koloni. Bakteri dominan yang diambil adalah bakteri yang jumlah koloninya tidak lebih tinggi dari 300 (karena akan sulit untuk dihitung dan kemungkinan salah dalam perhitungan sangat besar sehingga bakteri yang diambil dari pengenceran adalah koloni antara 30-300 koloni bakteri) dan koloni bakteri yang lebih sering dijumpai atau lebih banyak tumbuh pada semua pengenceran yang dilakukan.

Isolat bakteri R1, R2, R4, R5 dan R6 hanya terdapat pada beberapa pengenceran, dan pada beberapa pengenceran lain tidak tumbuh sama sekali. Isolat bakteri R3 memiliki jumlah 66 koloni pada pengulangan ke-2 dan sebanyak 11 koloni pada pengulangan ke- 3 . Isolat bakteri R7 memiliki jumlah 60 koloni pada pengulangan ke- 2 dan sebanyak 88 koloni pada ulangan ke- 3. Isolat bakteri R3 dan R7 dipilih karena koloni kedua bakteri tersebut hampir terdapat pada semua pengenceran yang dilakukan. Selain itu jumlah koloni kedua bakteri juga memenuhi syarat untuk dilakukan inokulasi lalu dilakukan pemurnian bakteri.

Setelah didapatkan koloni murni dilanjutkan karakterisasi bakteri dengan mengamati bentuk, warna, tepi, dan elevasi dari koloni bakteri serta bentuk sel dan warna sel dari pewarnaan Gram yang dilakukan. Uji katalase untuk melihat kemampuan memproduksi enzim katalase ditunjukkan dengan terbentuknya gelembung. Selanjutnya dilakukan uji fermentasi karbohidrat untuk mengetahui kemampuan memfermentasi karbohidrat (glukosa, sukrosa dan laktosa). Uji nitrat untuk mengetahui ada tidaknya aktifitas bakteri dalam mereduksi nitrat oleh adanya enzim nitrat reduktase. Uji indol dilakukan untuk mengetahui ada tidaknya aktifitas bakteri dalam menguraikan asam amino triptopan menjadi indol (Jutono dkk., 1980).

Tabel 1. Karakterisasi Koloni Bakteri Dominan pada Limbah Cair Tahu

\begin{tabular}{|c|c|c|c|c|c|c|c|c|c|c|c|c|}
\hline \multirow{3}{*}{ Isolat } & \multirow{3}{*}{ Bentuk } & \multirow{3}{*}{ Tepi } & \multirow{3}{*}{ Elevasi } & \multirow{3}{*}{ Warna } & \multicolumn{2}{|c|}{ Pengecatan Gram } & \multicolumn{6}{|c|}{ Uji Biokimia } \\
\hline & & & & & Bentuk & Warna & & F.K & & & & \\
\hline & & & & & Sel & Sel & G & $\mathbf{S}$ & $\mathbf{L}$ & $\mathbf{N}$ & I & $\mathbf{K}$ \\
\hline $\mathbf{R 3}$ & Circular & Entire & Flat & Putih Susu & Basil & Ungu & + & - & - & - & + & + \\
\hline R7 & Circular & Entire & Flat & $\begin{array}{c}\text { Putih } \\
\text { kekuningan }\end{array}$ & Kokus & Merah & + & + & - & - & + & + \\
\hline
\end{tabular}

Keterangan : F.K (Fermentasi Karbohidrat), G (Glukosa), S (Sukrosa), L (Laktosa), $\mathrm{N}$ (Nitrat), I (Indol), K (Katalase), + (positif), - (negatif)

Berdasarkan beberapa hasil uji yang telah dilakukan pada Tabel 1 diperkirakan isolat bakteri R3 merupakan bakteri genus Pseudomonas, sedangkan isolat bakteri R7 diperkirakan genus Bacillus. Kedua isolat tersebut mampu menghasilkan enzim protease untuk mendegradasi bahan organik di dalam limbah khususnya protein. 
Ken $d k k$,

\section{Derajat Keasaman (pH) dan Suhu}

Tabel 2. $\mathrm{pH}$ pada biodegradasi limbah cair tahu (inkubasi selama 7 hari)

\begin{tabular}{ccccc}
\hline \hline Hari ke- & K & A & B & C \\
\hline \hline 0 & 3,49 & 3,44 & 3,39 & 3,46 \\
1 & 3,47 & 3,58 & 3,49 & 3,59 \\
2 & 3,73 & 3,74 & 3,57 & 3,64 \\
3 & 3,76 & 3,96 & 3,66 & 3,71 \\
4 & 3,93 & 4,1 & 3,8 & 3,87 \\
5 & 4,42 & 4,43 & 3,85 & 4,2 \\
6 & 4,67 & 4,9 & 3,96 & 4,76 \\
7 & 5,56 & 5,2 & 4,14 & 5,21 \\
\hline \hline
\end{tabular}

Keterangan : K (Kontrol), A (Perlakuan A: penambahan bakteri R3), B (Perlakuan B: penambahan bakteri R7), dan C (Perlakuan C: penambahan bakteri R3 dan R7)

Tabel 3. Suhu pada biodegradasi limbah cair tahu (inkubasi selama 7 hari)

\begin{tabular}{ccccc}
\hline \hline Hari ke- & $\mathbf{K}\left({ }^{\circ} \mathbf{C}\right)$ & $\mathbf{A}\left({ }^{\circ} \mathbf{C}\right)$ & $\mathbf{B ~}\left({ }^{\circ} \mathbf{C}\right)$ & $\mathbf{C}\left({ }^{\circ} \mathbf{C}\right)$ \\
\hline \hline 0 & 27,4 & 27,8 & 27,4 & 27,3 \\
1 & 27,7 & 27,9 & 27,6 & 27,5 \\
2 & 27,8 & 28,1 & 27,8 & 28 \\
3 & 28,1 & 28,3 & 28,4 & 28,1 \\
4 & 28 & 28,3 & 28,2 \\
5 & 28,2 & 28,3 & 28,3 & 28,4 \\
6 & 28,9 & 28,6 & 28,4 & 28,5 \\
7 & 29 & 28,6 & 28,2 & 28,7 \\
\hline \hline
\end{tabular}

Keterangan : K (Kontrol), A (Perlakuan A: penambahan bakteri R3), B (Perlakuan B: penambahan bakteri R7), dan C (Perlakuan C: penambahan bakteri R3 dan R7)

Berdasarkan Tabel $2 \mathrm{pH}$ di awal perlakuan pada hari sebelum aplikasi berkisar pada angka 3,4 dan perlahan mengalami kenaikan secara konstan dengan nilai $\mathrm{pH}$ antara 4,0 sampai 5,6 pada hari setelah pemberian perlakuan. Hal tersebut dapat terjadi karena adanya penguraian bahan organik yang ditunjukkan dengan kenaikan nilai $\mathrm{pH}$ mendekati netral dan munculnya bau busuk dari gas amonia saat pemecahan protein yang dilakukan oleh mikrobia. Suatu mekanisme proses dekomposisi bahan organik dari limbah cair tahu oleh mikroorganisme mempunyai reaksi seperti berikut:

$$
\begin{aligned}
& \mathrm{C}_{\mathrm{x}} \mathrm{H}_{\mathrm{y}} \mathrm{O}_{\mathrm{z}} \mathrm{N}_{2} \mathrm{~S}+\text { Bakteri }+\mathrm{O}_{2} \\
& \mathrm{CO}_{2}+\mathrm{H}_{2} \mathrm{O}+\mathrm{NH}_{3}+\mathrm{C}_{\mathrm{x}} \mathrm{H}_{\mathrm{y}} \mathrm{O}_{2} \mathrm{~N}
\end{aligned}
$$

Berdasarkan reaksi, lingkungan yang dihasilkan dari proses adalah bersifat basa karena adanya pembentukan ammonia, apabila reaksi yang terbentuk berupa $\mathrm{NH}^{+}$maka sifat lingkungannya adalah asam (Effendi, 2003). Berdasarkan Peraturan Gubernur DIY No.7 Tahun 2010 nilai standar $\mathrm{pH}$ pada limbah cair tahu yang berkisar antara 6,0-9,0, meskipun belum terlihat jelas angka $\mathrm{pH}$ pada setiap perlakuan terus mengalami peningkatan sehingga hampir mendekati standar $\mathrm{pH}$ yang diberikan.

Berdasarkan Tabel 3 dapat dilihat bahwa suhu pada perlakuan $\mathrm{K}, \mathrm{A}, \mathrm{B}$ dan $\mathrm{C}$ mengalami kenaikan setiap harinya meskipun tidak meningkat secara cepat. Suhu awal hari sebelum perlakuan sekitar $27^{\circ} \mathrm{C}$, sedangkan pada hari ke-7 setelah perlakuan suhu meningkat menjadi sekitar $28^{\circ} \mathrm{C}$. Kenaikan suhu pada saat proses bioremediasi berlangsung dapat terjadi karena faktor lingkungan di sekitar tempat bioremediasi seperti kelembaban lingkungan, cuaca di sekitar serta cahaya matahari. Kelembaban dan adanya sinar matahari juga memengaruhi tinggi rendahnya suhu. Berdasarkan Peraturan Gubernur DIY No.7 Tahun 2010 nilai standar suhu pada limbah cair tahu maximal adalah $38^{\circ} \mathrm{C}$ sehingga suhu akhir pada penelitian sudah di bawah standar baku mutu yang ditentukan. 
Tabel 4. Konsentrasi COD pada biodegradasi limbah cair tahu

\begin{tabular}{cccccc}
\hline \hline Perlakuan & K (mg/L) & A (mg/L) & B (mg/L) & C (mg/L) & $\begin{array}{c}\text { Standar max. } \\
\text { Peraturan } \\
\text { Gubernur DIY }\end{array}$ \\
\hline \hline Sebelum & 5756,37 & 5794,03 & 5791,63 & 5743,8 & $200 \mathrm{mg} / \mathrm{L}$ \\
Sesudah & 5990,9 & 5709,78 & 5710,83 & 5672,87 & \\
\hline \hline
\end{tabular}

Keterangan : K (Kontrol), A (Perlakuan A: penambahan bakteri R3), B (Perlakuan B: penambahan bakteri R7), dan C (Perlakuan C: penambahan bakteri R3 dan R7)

Tabel 5. Konsentrasi BOD5 pada biodegradasi limbah cair tahu

\begin{tabular}{lccccc}
\hline \hline Perlakuan & K & A & B & C & $\begin{array}{c}\text { Standar max. } \\
\text { Peraturan } \\
\text { Gubernur DIY }\end{array}$ \\
\hline \hline Sebelum & 133,6 & 120,27 & 122,87 & 114,73 & $75 \mathrm{mg} / \mathrm{L}$ \\
Sesudah & 107,47 & 81,07 & 111,47 & 88,4 & \\
\hline \hline
\end{tabular}

Keterangan : K (Kontrol), A (Perlakuan A: penambahan bakteri R3), B (Perlakuan B: penambahan bakteri R7), dan C (Perlakuan C: penambahan bakteri R3 dan R7)

Berdasarkan Tabel 4 menunjukkan bahwa pada perlakuan $\mathrm{C}$ mengalami penurunan kadar COD terbesar dan disusul oleh perlakuan A dan B. Penurunan ini dapat terjadi karena senyawa organik teroksidasi penuh menjadi karbon dioksida dengan agen oksidasi yang kuat dalam kondisi asam, sedangkan peningkatan pada perlakuan kontrol dapat terjadi karena faktor lingkungan seperti kandungan oksigen terlarut dalam limbah. Sinar matahari mempengaruhi tinggi rendahnya nilai COD, sinar matahari dapat mengakibatkan fotosintesis yang menghasilkan oksigen berlebih (Rizki dkk., 2007).

Nilai BOD5 mengalami penurunan dari hari sebelum perlakuan sampai hari setelah diberikan perlakuan. Hal tersebut menunjukkan adanya aktivitas bakteri yang memfermentasi bahan organik pada limbah cair tahu menjadi senyawa asam laktat yang berfungsi mempercepat perombakan bahan organik mikroorganisme merombak bahan organik menjadi senyawa organik sederhana seperti $\mathrm{CO}_{2}$ dan $\mathrm{NH}_{3}$ yang secara tidak langsung dapat menurunkan nilai BOD5 (Yulvizar, 2015).

Kadar COD dan BOD5 pada perlakuan yang diberikan menunjukkan hasil yang masih berada di atas kadar maksimum standar mutu Peraturan Gubernur DIY No.7 Tahun 2010, walaupun begitu konsentrasi dari kedua parameter mengalami penurunan.

\section{TDS dan TSS}

Tabel 6. Konsentrasi TDS pada biodegradasi limbah cair tahu

\begin{tabular}{cccccc}
\hline \hline Hari/Perlakuan & $\mathbf{K}(\mathbf{m g} / \mathbf{L})$ & $\mathbf{A}(\mathbf{m g} / \mathbf{L})$ & $\mathbf{B}(\mathbf{m g} / \mathbf{L})$ & $\mathbf{C}(\mathbf{m g} / \mathbf{L})$ & $\begin{array}{c}\text { Standar max. } \\
\text { Peraturan Gubernur } \\
\text { DIY }\end{array}$ \\
\hline \hline H0 & 114,33 & 107 & 112,33 & 113,33 & \\
H1 & 116,33 & 111,33 & 112,67 & 114,67 & \\
H2 & 117,67 & 113 & 114,67 & 116 & $1000 \mathrm{mg} / \mathrm{L}$ \\
H3 & 120 & 117,33 & 117,33 & 118 & \\
H4 & 128 & 120,67 & 124 & 123,67 & \\
H5 & 126,33 & 118,33 & 127,67 & 131,33 & 129,67 \\
H6 & 132,67 & 124,67 & 130,67 & 137 & \\
H7 & 139 & 129,33 & 135,57 & 137 & \\
\hline \hline
\end{tabular}

Keterangan : K (Kontrol), A (Perlakuan A: penambahan bakteri R3), B (Perlakuan B: penambahan bakteri R7), dan C (Perlakuan C: penambahan bakteri R3 dan R7); H0 (Hari ke-0 inkubasi), H1 (Hari ke-1 inkubasi), H2 (Hari ke-2 inkubasi), H3 (Hari ke-3 inkubasi), H4 (Hari ke-4), H5 (Hari ke-5), H6 (Hari ke-6 inkubasi), H7 (Hari ke-7 inkubasi) 
Berdasarkan Tabel 6 dapat diketahui bahwa dari hari sebelum diberikan perlakuan hingga hari terakhir setelah diberikan perlakuan konsentrasi TDS mengalami peningkatan hal tersebut dapat terjadi karena proses pemecahan bahan organik berukuran besar menjadi berukuran lebih kecil yang sebelumnya termasuk dalam suspended solid. Meskipun begitu seharusnya nilai TDS semakin turun karena bahan organik tersebut digunakan oleh mikroorganisme sebagai sumber energinya hal ini mungkin terjadi karena proses penggunaan bahan organik oleh mikroorganisme belum sempurna (Paramita dkk., 2012). Walaupun konsentrasi TDS meningkat namun kadar ini sudah termasuk di bawah standar maksimum standar mutu
Peraturan Gubernur DIY No.7 Tahun 2010 kadar maksimum TDS adalah $1000 \mathrm{mg} / \mathrm{L}$.

Konsentrasi TSS pada limbah cair tahu terlihat menurun setelah diberi perlakuan. Perlakuan $\mathrm{C}$ merupakan perlakuan dengan penambahan bakteri yang menurunkan kadar TSS paling banyak dibandingkan yang lain. Penurunan kadar TSS belum memenuhi standar mutu Peraturan Gubernur DIY No.7 Tahun 2010 kadar maksimum TSS adalah 75 $\mathrm{mg} / \mathrm{L}$, tetapi konsentrasinya terus menurun yang dapat terjadi karena proses degradasi mikroorganisme pada limbah cair tahu karena bahan organiknya (protein, lemak dan karbohidrat) pada proses hidrolisis. Padatan tersuspensi menjadi bentuk terlarut sehingga nilai TSS menjadi berkurang (Paramita dkk., 2012).

Tabel 7. Konsentrasi N-Total pada biodegradasi limbah cair tahu

\begin{tabular}{ccc}
\hline \hline Perlakuan & $\begin{array}{c}\text { Sebelum } \\
\text { Proses biodegradasi (\%) }\end{array}$ & $\begin{array}{c}\text { Sesudah } \\
\text { Proses biodegradasi (\%) }\end{array}$ \\
\hline \hline K & 0.56 & 0.67 \\
A & 0.53 & 0.46 \\
B & 0.57 & 0.54 \\
C & 0.5 & 0.45 \\
\hline \hline
\end{tabular}

Keterangan : K (Kontrol), A (Perlakuan A: penambahan bakteri R3), B (Perlakuan B: penambahan bakteri R7), dan C (Perlakuan C: penambahan bakteri R3 dan R7)

\section{N-Total dan Karbohidrat (Amilum)}

Berdasarkan Tabel 7 dapat diketahui bahwa kadar N-Total pada perlakuan A, B dan $\mathrm{C}$ mengalami penurunan, hal tersebut dapat terjadi karena nitrogen dalam limbah berasal dari nitrogen organik dalam bentuk protein, semakin lama waktu degradasi nitrogen tersebut akan diubah menjadi amonia dan terlepas di udara dalam bentuk amonia bebas sehingga konsentrasi nitrogen dapat berkurang di dalam limbah (Effendi, 2003), sedangkan peningkatan konsentrasi N-total pada perlakuan kontrol dapat terjadi karena adanya pengaruh perombakan bahan organik dalam tubuh mikroorganisme yang menghasilkan protein sel tunggal. Saat mikrorganisme melakukan perombakan bahan organik, di dalam tubuh mikroorganisme tersebut juga menghasilkan protein sel tunggal yang pada saat mikroorganisme tersebut mati, maka protein sel tunggal tersebut akan dilepaskan ke lingkungan sehingga kadar nitrogen di lingkungan akan bertambah (Wijaya, 2008).

Kadar karbohidrat pada perlakuan kontrol dan perlakuan A mengalami peningkatan yang dapat terjadi karena pada hari sebelum diberikan perlakuan masih terdapat senyawa kompleks lain yang belum terombak menjadi amilum (senyawa sederhana lain) dan selama proses biodegradasi setelah diberikan perlakuan senyawa kompleks tersebut baru terdegradasi menjadi amilum sehingga kadar amilum pada limbah cair tersebut meningkat. Pada perlakuan B dan C mengalami penurunan kadar karbohidrat saat proses biodegradasi yang dapat terjadi karena proses degradasi amilum oleh mikroorganisme yang menghasilkan senyawa yang lebih sederhana dan digunakan oleh mikroorganisme sebagai sumber energi untuk proses degradasi senyawa organik lainnya dan untuk metabolisme (Pohan, 2008). 
Tabel 8. Konsentrasi Karbohidrat (amilum) pada biodegradasi limbah cair tahu

\begin{tabular}{ccc}
\hline \hline \multirow{2}{*}{ Perlakuan } & $\begin{array}{c}\text { Sebelum } \\
\text { Proses biodegradasi (\%) }\end{array}$ & $\begin{array}{c}\text { Sesudah } \\
\text { Proses biodegradasi (\%) }\end{array}$ \\
\hline K & 0.24 & 0.25 \\
A & 0.28 & 0.29 \\
B & 0.27 & 0.15 \\
C & 0.3 & 0.19 \\
\hline
\end{tabular}

Keterangan : K (Kontrol), A (Perlakuan A: penambahan bakteri R3), B (Perlakuan B: penambahan bakteri R7), dan C (Perlakuan C: penambahan bakteri R3 dan R7)

Tabel 9. Hasil Analisis akhir parameter uji

\begin{tabular}{ccccccc}
\hline \hline \multirow{2}{*}{ Perlakuan } & \multicolumn{7}{c}{ \% Penurunan dan kenaikan parameter uji } \\
\cline { 2 - 7 } & COD & BOD5 & TSS & TDS & Karbohidrat (Amilum) & N-Total \\
\hline Kontrol & $+4 \%$ & $20 \%$ & $9 \%$ & $+21 \%$ & $+4,3 \%$ & $+19 \%$ \\
A & $1 \%$ & $33 \%$ & $2,9 \%$ & $+21 \%$ & $+1,9 \%$ & $12 \%$ \\
B & $1 \%$ & $9 \%$ & $6 \%$ & $+21 \%$ & $46 \%$ & $5,2 \%$ \\
C & $1 \%$ & $23 \%$ & $8,1 \%$ & $+21 \%$ & $34 \%$ & $8,9 \%$ \\
\hline \hline
\end{tabular}

Keterangan: $+=$ terjadi kenaikan kadar parameter uji

Berdasarkan Tabel 9 diketahui bahwa Penurunan kadar terbaik terdapat pada perlakuan $\mathrm{C}$ dengan penambahan bakteri R3 dan R7 karena dapat menurunkan lebih banyak parameter yang diuji dibandingkan pada perlakuan yang lain. Perlakuan tersebut dapat menurunkan COD $\pm 1 \%$, BOD5 $\pm 23 \%$, TSS $8,1 \%$, Amilum 34\%, N-Total 8,9\%, namun menaikkan TDS sebanyak $21 \%$.

\section{Simpulan}

Bakteri R3 diperkirakan bakteri genus Pseudomonas dengan karakteristik koloni berbentuk circular, tepi entire, elevasi flat, warna putih kekuningan, bentuk sel kokus dan warna merah dan gram negatif, uji glukosa dan sukrosa positif, indol dan katalase positif, uji nitrat negatif, sedangkan isolat bakteri R7 diperkirakan genus Bacillus dengan karakteristik koloni berbentuk circular, tepi entire, elevasi flat, warna putih susu, bentuk sel basil dan warna sel ungu dan gram positif, uji glukosa positif, uji sukrosa dan laktosa serta nitrat negatif, uji indol dan katalase positif.

Kombinasi bakteri R3 dan R7 lebih efektif mendegradasi limbah organik pada limbah cair tahu dibandingkan penggunaan isolat tunggal, karena mampu menaikkan $\mathrm{pH}$ dan suhu paling cepat serta menurunkan : COD sebanyak $\pm 1 \%$, BOD5 sebanyak $\pm 23 \%$, TDS sebanyak $21 \%$, TSS sebanyak $8,1 \%$, N-Total sebanyak 8,9\% dan karbohirat (amilum) sebanyak $34 \%$.

\section{Saran}

Berdasarkan penelitian yang telah dilakukan disarankan untuk dilakukan pengujian lebih lanjut (seperti identifikasi molekuler) terhadap bakteri indigenus dominan yang ditemukan di dalam limbah cair tahu. Selain itu, juga disarankan melakukan uji parameter tambahan untuk memastikan proses biodegradasi berjalan dengan benar, misalnya seperti pengukuran kandungan lemak dalam limbah cair tahu dan uji nitrat dan nitrit.

\section{Daftar Pustaka}

Effendi, H. 2003. Telaah Kualitas Air bagi Pengelolaan Sumber Daya dan Lingkungan Perairan. Cetakan Kelima. Yogyakarta : Kanisius.

Jutono, J. Soedarsono, S. Hartadi, S. Kabirun, S. Suhadi, D. dan Soesanto. 1980. Pedoman Praktikum Mikrobiologi Umum. Departemen Mikrobiologi Fakultas Pertanian UGM, Yogyakarta.

Pohan. 2008. Pengolahan Limbah Cair Industri Tahu dengan Proses Biofilter Aerobik. Sekolah Pascasarjana Universitas Sumatera Utara, Medan.

Paramita, P., Shovitri, M. dan N. D. Kuswytasari. 2012. Biodegradasi Limbah Organik Pasar dengan Menggunakan Mikroorganisme Alami 
Tangki Septik. Jurnal Sains dan Seni ITS 1(1): 23.

Pemerintah Daerah Istimewa Yogyakarta. 2010. Peraturan Gubernur Daerah Istimewa Yogyakarta Nomor 7 Tahun 2010 Baku Mutu Limbah Cair Bagi Kegiatan Industri, Pelayanan Kesehatan dan Jasa Pariwisata. Pemerintah Daerah Istimewa Yogyakarta. Yogyakarta.

Rizki, N., Sutrisno, E. dan Sumiyati, S. 2007. Penurunan Konsentrasi COD dan TSS pada Limbah Cair Tahu dengan Teknologi Kolam (POND)Biofilm Menggunakan Media Biofilter Jaring Ikan dan Bioball. Program Studi Teknik Lingkungan Fakultas Teknik Universitas Diponegoro, Semarang.
Wigyanto, Nur Hidayat dan Alfia Ariningrum. 2009. Bioremediasi Limbah Cair Sentra Industri Tempe Sanan Serta Perencanaan Unit Pengolahannya (Kajian Pengaturan Kecepatan Aerasi Dan Waktu Inkubasi). Jurnal Teknologi Pertanian. Vol. 10 (2): 123135.

Wijaya, Bayu. 2008. Potensi Limbah Cair Tahu untuk Produksi Biogas sebagai Energi Alternative. UGM, Yogyakarta.

Yulvizar, C., Ismail, Y.S., Moulana, R. 2015. Karakteristik bakteri asam laktat indegenous dari jeruk drien, Provinsi Aceh. Jurnal Teknologi dan Industri Pertanian 7(1): 31-34. 